\title{
EFEKTIVITAS PEMBERIAN SMOOTHIES KOMBINASI ANEKA BUAH DAN SAYUR TERHADAP PERUBAHAN TEKANAN DARAH PADA WANITA DEWASA
}

\section{EFFECTIVENESS OF GIVING COMBINATION SMOOTHIES OF VARIOUS FRUITS AND VEGETABLES TO BLOOD PRESSURE CHANGE IN ADULT WOMEN}

\author{
Ina Mutma'inah*); Mohammad Jaelani; Cahyo Hunandar
}

\begin{abstract}
Background : Hypertension is a long term condition in which blood pressure is higher than 140/90 $\mathrm{mmHg}$. Antihypertensive drugs therapy took a long time and caused side effects so that further treatment is needed through non-pharmalogycal therapy such as the consumption of smoothies combination of various fruits and vegetables that contain high fiber and potassium.

Objective : To determine the effectiveness of smoothies combination of various fruits and vegetables consumtion to changes in blood pressure change in adult women.

Method : This research is a true experiment with Randomized Pre and Post Test Control Group Design. Sampling was done randomly to get 30 samples. Data collection were included by age, nutritional status, occupation, blood pressure data before and after treatment and fiber, sodium, potassium, calcium and magnesium intakes.

Results : There was an effect of smoothies combination of various fruits and vegetables consumtion to decrease cytolic and diastolic blood pressure during the study with confounding variables of fiber, sodium, potassium and magnesium intake ( $p=0.025$ and $p=0.037$ ).

Conclusion : The average systolic and diastolic blood pressure in the treatment group were decreased after consumtion smoothies combination of various fruits and vegetables, while the control group tended to increased because they were not consume smoothies.
\end{abstract}

Keywords : Smoothies combination of various fruits and vegetables, Blood Pressure.

\section{ABSTRAK}

Latar Belakang : Hipertensi merupakan keadaan meningkatnya tekanan darah secara kronis mencapai $\geq 140 / 90$ $\mathrm{mmHg}$. Penggunaan obat-obatan antihipertensi membutuhkan waktu yang lama dan menimbulkan efek samping sehingga diperlukan penanganan nonfarmakologi melalui konsumsi smoothies kombinasi aneka buah dan sayur yang mengandung serat dan kalium yang tinggi.

Tujuan : untuk mengetahui efektivitas pemberian smoothies kombinasi aneka buah dan sayur terhadap perubahan tekanan darah pada wanita dewasa.

Metode : Jenis Penelitian ini adalah true experiment dengan rancangan Randomized Pre and Post Test ControlGroup Design. Pengambilan sampel secara acak sebanyak 30 sampel untuk kelompok kontrol dan perlakuan. Data yang dikumpulkan yaitu usia, status gizi, pekerjaan, tekanan darah sebelum dan setelah perlakuan serta asupan serat, natirum, kalium, kalsium dan magnesium.

Hasil : Ada pengaruh pemberian smoothies kombinasi aneka buah dan sayur terhadap penurunan tekanan darah sitolik dan diastolik selama penelitian dengan variabel konfonding asupan serat, natrium, kalium dan magnesium $(p=0.025$ dan $p=0,037)$.

Kesimpulan : Rata-rata tekanan darah sistolik dan diastolik pada kelompok perlakuan menurun setelah diberikan smoothies, sedangkan kelompok kontrol cenderung meningkat karena tidak diberi smoothies.

Kata Kunci : Smoothies kombinasi aneka buah dan sayur, Tekanan Darah. 


\section{PENDAHULUAN}

Hipertensi merupakan peningkatan tekanan darah pada pembuluh darah secara kronis yaitu tekanan sistolik mencapai $\geq 140 \mathrm{mmHg}$ dan tekanan diastolik mencapai $\geq 90 \mathrm{mmHg}$. ${ }^{1}$ Tekanan darah yang terus meningkat dapat menimbulkan arterosklerosis sehingga menyebabkan ganggguan sistem makrovaskuler dan mikrovaskuler. ${ }^{2}$

Pemerintah telah melakukan penanganan hipertensi melalui beberapa tindakan salah satunya dengan pemberian obat antihipertensi. Penggunaan obat antihipertensi menimbulkan efek samping jika dikonsumsi dalam jangka waktu lama sep erti pusing, hiperurisemia, hipotensi, udem periferal, nyeri perut, dll ${ }^{3}$. Untuk mengurangi efek samping dibutuhkan alternatif penanganan melalui terapi nonfarmakologi dengan cara modifikasi diet. Salah satunya dengan mengkonsumsi sayur dan buah yang tinggi akan mikronutrien, zat fitokimia dan antioksidan yang berfungsi menurunkan tekanan darah sehingga dosis obat yang dikonsumsi dapat diturunkan secara perlahan. ${ }^{4}$

Kalium dapat menghambat pelepasan renin dalam urin dengan cara mengurangi jumlah natrium, berperan dalam sistem renin-angiotensin yang menjadi pusat kontrol utama tekanan darah dan fungsi endokrin terkait sistem kardiovaskuler. ${ }^{5}$ Zat fitokimia dan antioksidan menurunkan tekanan darah dengan cara menurunkan penyerapan kolesterol sehingga menghambat arterosklerosis, memodulasi pengeluaran nitric oxide yang bersifat vasodilator dII. ${ }^{5,6}$

Asupan kalium, zat fitokimia dan antioksidan dapat diperoleh dengan mengkonsumsi buah dan sayur seperti buah naga, jambu biji, alpukat, wortel dan tomat. ${ }^{7}$ Dalam sehari seseorang dengan hipertensi dianjurkan mengkonsumsi buah dan sayuran minimal 4-5 porsi sehari berdasarkan diet DASH (Dieraty Approaches to Stop Hypertension). ${ }^{8}$

Smothies aneka buah dan sayur merupakan salah satu alternatif modifikasi diet bagi penderita hipertensi. Buah dan sayur yang dikonsumsi dalam bentuk smothies akan lebih meningkatkan daya terima dan daya cerna buah serta sayur karena teksturnya yang lebih halus dan volumenya yang lebih kecil. Untuk mendapatkan produk smothies yang memiliki kandungan gizi lengkap seperti tinggi kalium, serat, lycopene dan flavonoid dibutuhkan beberapa kombinasi buah dan sayur.

Tujuan penelitian ini untuk menganalisis efektivitas pemberian smoothies kombinasi aneka buah dan sayur terhadap perubahan tekanan darah pada wanita dewasa.

\section{METODE}

Untuk mencapai tujuan dilakukan penelitian dengan menggunakan Rancangan Randomized Repeated Measure Control Group Design). Pada penelitian ini, subjek yang memenuhi kriteria inklusi dikelompokkan menjadi 2, yaitu kelompok perlakuan (diberi smoothies kombinasi aneka buah dan sayur sebanyak $350 \mathrm{ml}$ ) dan kelompok kontrol (tidak diberi).

Penelitian dilakukan di Kelurahan Pedurungan Tengah RW 02 dan RW 09 Kecamatan Pedurungan, Kota Semarang yang terdiri dari 30 orang dan dilakukan selama 21 hari (14 April - 05 Mei 2018). Sampel dalam penelitian ini adalah wanita dewasa dengan status gizi overweight atau obesitas usia 30-64 tahun, sehat, tidak meminum obat antihipertensi atau obat yang dapat meningkatkan hipertensi serta bersedia berperan dalam penelitian. Perhitungan subjek menggunakan rumus Lemeshow. Jumlah seluruh sampel penelitian yaitu 30 orang dengan masingmasing 15 orang pada setiap kelompok.

Kelompok perlakuan dalam penelitian ini diberi smoothies kombinasi aneka buah dan sayur sebanyak $350 \mathrm{ml}$ yang diberikan 1 kali perhari pada sore hari yang dikonsumsi sebagai snack, sedangkan kelompok kontrol tidak diberi smoothies kombinasi aneka buah dan sayur. Smoothies yang diberikan memiliki 4 variasi kombinasi buah dan sayur yaitu kombinasi 1 (wortel, alpukat dan buah naga), kombinasi 2 (wortel, alpukat dan jambu biji), kombinasi 3 ( alpukat, jambu biji dan tomat) dan kombinasi 4 (alpukat, buah naga dan tomat). Variabel dependent yaitu Tekanan darah sistolik dan diastolik wanita dewasa yang diukur pada awal dan akhir intervensi (7 hari sekali dalam 21 hari) menggunakan Sphygmomanmeter Digital merek Family Dr. Variabel independent yaitu pemberian smoothies kombinasi aneka buah dan sayur.

Instrumen yang digunakan terdiri dari formulir identitas sampel penelitian, formulir informed concern, formulir pengukuran tekanan darah, Formulir checklist asupan Smohies kombinasi aneka buah dan sayur dan formulir recall 3 x24 jam. Penentuan status gizi dari hasil pengukuran $B B$ yang diukur menggunakan timbangan digital merek GEA dan TB yang diukur menggunakan microtoice. Data tekanan darah diuku rmenggunakan Sphygmomanmeter Digital merek Family Dr pada saat sebelum dan sesudah intervensi (7 hari sekali dalam 21 hari). Data asupan serat, natrium, kalium, kalsium dan magnesium yang dikonsumsi diperoleh menggunakan metode food recall3 x 24 jam dengan waktu yang tidak berurutan.

Analisis univariat digunakan untuk mengetahui distribusi frekuensi subjek penelitian berdasarkan, usia, status gizi, pekerjaan, kejadian 
hipertensi, asupan serat, natrium, kalium, kalsium dan magnesium. Analisis bivariat digunakan untuk mengetahui perbedaan asupan sebelum dan sesudah diberikan perlakuan pada setiap kelompok menggunakan uji Independent T-Test serta perbedaan tekanan darah sebelum dan sesudah diberikan perlakuan pada setiap kelompok perlakuan menggunakan uji Mann Whitney. Analisis multivariat dilakukan menggunakan uji Anova Reapeted Measure dengan dengan faktor yang dikontrol yaitu asupan serat, natrium, kalium, kalsium dan magnesium.

\section{HASIL PENELITIAN}

Penelitian ini dilakukan di RW 02 dan RW 09, Kelurahan Pedurungan Tengah Kecamatan Pedurungan Kota Semarang dengan jumlah sampel penelitian 30 orang. Penelitian dilaksanakan selama 21 hari dimulai tanggal 14 April 2018 sampai dengan 5 Mei 2018.

\section{Karakteristik Subjek Penelitian}

Tabel 1 menunjukkan sebagian besar umur sampel penelitian termasuk dalam kategori dewasa (30-49 tahun), yaitu sebanyak 18 orang (60,0 \%). Karakteristik sampel berdasarkan status gizi sebagian besar sampel penelitian memiliki status gizi obesitas tipe I $\left(25,0-29,9 \mathrm{~kg} / \mathrm{m}^{2}\right)$ sebanyak 15 orang $(50 \%)$. Dari 30 sampel penelitian 19 orang (63,3\%) diantara memiliki pekerjaan. Tekanan darah sampel penelitian diperoleh sebanyak 22 orang ( 73,3 \%) berapa pada status tekanan darah prehipertensi (>120/80 $\mathrm{mmHg}$ ) yang harus di waspadai.

Tabel 1. Distribusi Frekuensi Beberapa Karakteristik Sampel penelitian.

\begin{tabular}{|c|c|c|c|c|c|c|}
\hline \multirow{3}{*}{ Kategan } & \multicolumn{6}{|c|}{ Kalempak } \\
\hline & \multicolumn{2}{|c|}{ Rartakuan } & \multicolumn{2}{|c|}{ Kontral } & \multicolumn{2}{|c|}{ Total } \\
\hline & 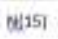 & 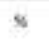 & 815) & 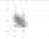 & $\operatorname{teg} \frac{0}{6}$ & 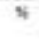 \\
\hline \multicolumn{7}{|l|}{ Umien (Thi } \\
\hline \multirow{2}{*}{$\begin{array}{l}\text { Devere }\{30-49\} \\
\text { Devase Ius }\{50-64 \mid\end{array}$} & & 513 & & & 16 & 600 \\
\hline & 7 & 45.7 & 5 & 333 & 11 & 40,0 \\
\hline \multicolumn{7}{|l|}{ Statuan giv } \\
\hline & & & & & 3 & \\
\hline 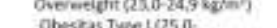 & 2 & 133 & 1 & 533 & 15 & 500 \\
\hline Obescas Twee t(25,0. & 9 & 600 & 6 & $60 \pi$ & 12 & \\
\hline 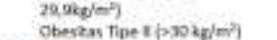 & 4 & 25.2 & $\varepsilon$ & 26,7 & & \\
\hline \multirow{2}{*}{\multicolumn{7}{|c|}{ Pakariaan }} \\
\hline $\begin{array}{l}\text { Cokscian } \\
\text { Beseria }\end{array}$ & & & & & 18 & 5.3 \\
\hline Tojet Eaberit. & 8 & 53.3 & 14 & 26,7 & 11 & 36,7 \\
\hline \multicolumn{7}{|l|}{ Tabanan Darah } \\
\hline Pretipertemi (120/85 mutes & & & & & 22 & 73,3 \\
\hline 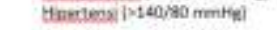 & a & 3nt & $t$ & 207 & 8 & 26.7 \\
\hline
\end{tabular}

Tabel 2 menunjukkan rata-rata pengukuran tekanan darah sistolik dan diastolik sebelum pemberian smoothies pada kelompok perlakuan yaitu 137/90 $\mathrm{mmHg}$ dan kelompok kontrol yaitu 133/88 mmHg. Tekanan darah sistolik dan diatolik pada kelompok perlakuan maupun kelompok kontrol termasuk kategori tekanan darah prehipertensi menurut Kementerian Kesehatan (2013).

Tabel 2. Karakteristik Rata-rata Tekanan Darah, Asupan Energi, Protein, Lemak, Karbohidrat, Serat, Natrium, Kalium, Kalsium dan Magnesium Sebelum Penelitian

\begin{tabular}{|c|c|c|c|c|c|c|}
\hline \multirow{3}{*}{ Verident } & \multicolumn{6}{|c|}{ Cotmest } \\
\hline & \multicolumn{3}{|c|}{ Buaknen } & \multicolumn{3}{|c|}{ Eested } \\
\hline & Mendsp & Mn. & $\max$ & Mentso & wh & Nas \\
\hline Sutseinentese & 1 istrance & $12 t$ & tar & Besorizs:14 & 104 & 200 \\
\hline Dancikjerates & Nadisice & $\pi$ & $\pm \infty$ & acrass & * & 191 \\
\hline $\operatorname{sen}(x)$ & $x=043$ & sis & $\mathrm{z}, \boldsymbol{*}$ & $10,30 n 2.56$ & $\omega$ & 16.2 \\
\hline numplos & 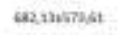 & se. & 14522 & 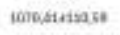 & $\times 0$ & antes \\
\hline $\tan i v e$ & 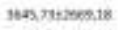 & sats, & manct & $\operatorname{sen}: 00+10 \%$ & twes? & mose \\
\hline themind & encensatas & went & $\operatorname{sene}$ & $50561600,30$. & 3596 & wox.9. \\
\hline Herevanise & 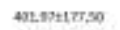 & $2 m 1$ & 200,3 & 52414085.22 & 2349 & wase \\
\hline
\end{tabular}

Tabel 3 menunjukkan bahwa asupan sampel penelitian sebelum perlakuan yaitu asupan serat sampel penelitian termasuk kategori kurang (<100\%) sebanyak 27 orang $(90,0 \%)$, asupan natirum sampel penelitian termasuk kategori kurang (<100\%) sebanyak 24 orang $(80,0 \%)$, asupan kalium sampel penelitian termasuk kategori kurang (<100\%) sebanyak 27 orang $(90,0 \%)$, asupan kalsium dan magnesium sampel penelitian $100 \%$ termasuk dalam kategori kurang (<100\%).

Tabel 3. Distribusi Frekuensi Berdasarkan Kategori Asupan Sampel Penelitian Sebelum Perlakuan

\begin{tabular}{|c|c|c|c|c|c|c|}
\hline \multirow{3}{*}{ Katagori Asupan } & \multicolumn{6}{|c|}{ Kelompok } \\
\hline & \multicolumn{2}{|c|}{ Perlabuer } & \multicolumn{2}{|c|}{ Kentral } & \multicolumn{2}{|c|}{ Tetal } \\
\hline & $N(15)$ & $\mathrm{N}$ & $N(15)$ & $\mathrm{s}$ & N(30) & 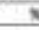 \\
\hline \multicolumn{7}{|l|}{ Serm } \\
\hline Kurang $/ 4008\}$ & 17 & $=0,0$ & is & 100 & 27 & w00 \\
\hline Bäh ceroon] & 3 & 20,0 & 0 & 0 & 3 & 100 \\
\hline \multicolumn{7}{|l|}{ Matrium } \\
\hline Brang ( 100 w & 12 & 80,0 & 12 & 80.0 & 24 & 8000 \\
\hline Aalk (to1000) & 3 & 20,0 & 3 & 20,0 & 6 & 20,0 \\
\hline \multicolumn{7}{|l|}{ calvem } \\
\hline Grans (c100N) & 14 & 93,3 & 13 & 86.7 & 27 & 900 \\
\hline Bas̆ [z100\%] & $t$ & 3,3 & 2. & 13,3 & 3 & 1000 \\
\hline \multicolumn{7}{|l|}{ Salnium } \\
\hline Suctant (-100s) & 15 & 100 & 15 & 100 & so & 100 \\
\hline \multicolumn{7}{|l|}{ Magnetium } \\
\hline Karand (crook) & 15 & 100 & 15 & 100 & 30 & 100 \\
\hline
\end{tabular}

\section{Asupan Smoothies Selama Penelitian}

Gambar 1 menunjukkan tingkat kepatuhan konsumsi smoothies kombinasi aneka buah dan sayur pada minggu pertama sampai minggu ke tiga baik yaitu diatas $95 \%$ dengan cut of point $80 \%$. Kelompok perlakuan 
mengkonsumsi smoothies dengan berbagai macam cara seperti meminum smoothies dalam keadaan dingin, meminum smoothies secara bertahap serta ada pula beberapa subjek yang langsung mengkonsumsi smoothies hingga habis setelah diberikan.

Smoothies yang paling disukai oleh sampel penelitian yaitu smoothies dengan kombinasi wortel, alpukat dan jambu biji yang memiliki tingkat kepatuhan paling tinggi dibandingkan dengan smoothies kombinasi buah dan sayur lainnya yaitu $99 \%$.

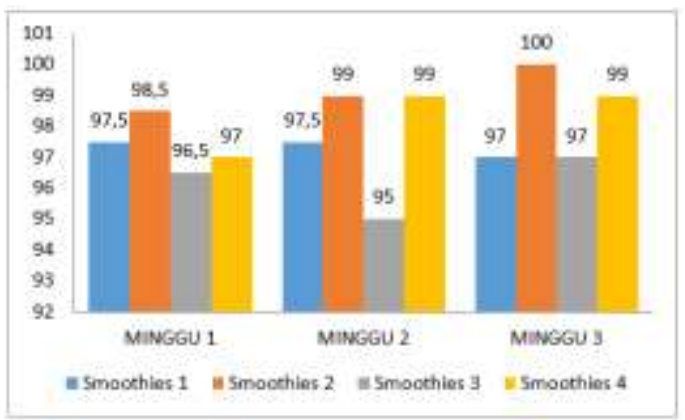

Gambar 1. Tingkat Kepatuhan Konsumsi Smoothies Kombinasi Aneka Buah dan Sayur Kelompok Perlakuan

3. Hasil Analisis Asupan Sampel Sebelum dan Sesudah Penelitian

Tabel 4 menunjukan hasil uji statistik independent sampel-test terhadap serat, natrium, kalium, kalsium dan magnesium sebelum perlakuan antara kelompok kontrol dan kelompok perlakuan tidak ada perbedaan yang signifikan $(p>0,005)$. Hal ini menunjukan bahwa data asupan sebelum penelitian anatara kelompok kontrol dan perlakuan tidak ada perbedaan yang signifikan. Sedangkan hasil uji statistik independent sampel-test terhadap asupan serat dan kalium setelah perlakuan antara kelompok kontrol dan kelompok perlakuan terdapat perbedaan yang signifikan $(p<0,005)$, sedangkan pada asupan natrium, kalsium dan magnesium tidak ada perbedaan yang signifikan $(p>0,005)$ karena bukan merupakan sumber natrium, kalsium dan magnesium.

Tabel 4. Perbedaan asupan serat, natirum, kalium, kalsium dan magnesium antara kelompok kontrol dengan kelompok perlakuan sebelum penelitian

\begin{tabular}{|c|c|c|c|}
\hline Anupur & $\begin{array}{l}\text { Keiompok Ferakusn } \\
\text { (n<-15) } \\
\text { Meunt50 }\end{array}$ & $\begin{array}{l}\text { Keiompok Kontrui } \\
\text { (pe15) } \\
\text { MeantsD }\end{array}$ & $p$ \\
\hline \multicolumn{4}{|c|}{ Sebelum Perlabsan } \\
\hline Serat & 4106019,75 & 3. $33+17,05$ & 0.048 \\
\hline Notrium & $69,46 \pm 81,54$ & $49,46 \pm 41,06$ & 0.101 \\
\hline collun & $50,00021,82$ & $43,65 \pm 47,07$ & 0,055 \\
\hline Katsham & $20.93 \pm 10,05$ & $17,56=8.71$ & 0.530 \\
\hline Magredum & 29.86410 .82 & $23,40=8.64$ & 0,142 \\
\hline \multicolumn{4}{|l|}{ Sotalah Porlakuan } \\
\hline Serat & $67,53 \div 12,19$ & $39,26 \pm 15,52$ & 0,000 \\
\hline Natrium & $n 7,20 \div 06,52$ & $40,13+45,25$ & $0,05:$ \\
\hline Kalum & $74,13 \div 17,04$ & 41,2 fi:s 37 & 0,000 \\
\hline Cosbiam & $60,0125,50$ & saxs+20.48 & $0,26 \mathrm{~s}$ \\
\hline Mapresim & $57,40=25,25$ & $75,065+36,32$ & 0.133 \\
\hline
\end{tabular}

4. Pengaruh Pemberian Smoothies Kombinasi Aneka Buah dan Sayur Terhadap Perubahan Tekanan Darah

Tabel 5 menunjukkan hasil analisis statistik menggunakan uji Independent sample $T$-Test bahwa ada perbedaan tekanan darah yang signifikan terhadap selisih tekanan darah sistolik sebelum dan sesudah perlakuan antara kelompok perlakuan dan kelompok kontrol $(p=0,000$ dan $p=0,000)$. Sedangkan hasil analisis statistik menggunakan uji Independent sample $T$-Test bahwa ada perbedaan tekanan darah yang signifikan terhadap selisih tekanan darah diastolik sebelum dan sesudah perlakuan antara kelompok perlakuan dan kelompok kontrol $(p=0,000$ dan $p=0,000)$.

Tabel 5. Selisih tekanan darah sistolik dan diastolik sebelum perlakuan antara kelompok kontrol dan kelompok perlakuan

\begin{tabular}{|c|c|c|c|}
\hline \multirow{2}{*}{ Takanan Darah } & Perlakum $(n=15)$ & $\frac{\text { Kontrol }}{(n=15)}$ & \multirow[t]{2}{*}{ p } \\
\hline & MoantSO & MeantsD & \\
\hline Sistolik Awrol - Aktir & $-16,80+10,86$ & $7,67 \geq 6,93$ & 0,000 \\
\hline Piastolik Awas - Asthic & $9,40 \pm 5,04$ & $4,0 \div 4,0$ & 0,000 \\
\hline
\end{tabular}

Independent Sample T-Test

\section{Perubahan Tekanan Darah Sebelum dan} Sesudah Penelitian

Tabel 6 menunjukkan hasil analisis statistik menggunakan uji Anova Repeated Measure didapatkan adanya perbedaan yang signifikan terhadap tekanan darah sistolik dan diastolik antara kelompok perlakuan dan kelompok kontrol selama 4 kali pengukuran dengan variabel yang dikontrol yaitu asupan serat, natrium, kalium, kalsium dan magnesium $(p=0,025$ dan $p=0,023)$. Dari hasil analisis dapat disimpulkan bahwa ada pengaruh pemberian smoothies kombinasi aneka buah dan sayur terhadap penurunan tekanan darah sistolik dan diastolik. 
Tabel 6. Tekanan darah sistolik dan diastolik selama penelitian dengan faktor pengganggu asupan serat, natrium, kalium, kalsium dan magnesium.

\begin{tabular}{|c|c|c|c|}
\hline \multirow{3}{*}{ Tekaneo Darah } & \multicolumn{3}{|c|}{ Kolempeoh } \\
\hline & Kantrol $(n+15)$ & Perlakuan (n=15) & p \\
\hline & Meentso & MeantSD & \\
\hline Sistolik Minses 1 & $137,73 \div 12,32$ & $133,87 \pm 21,14$ & \\
\hline Gistodik Mrnesed 2 & $128,93,9,77$ & $139,00+24,46$ & 0,025 \\
\hline Sistolis Mrese 3 & $124,33 \div 9,63$ & $141,13+24,45$ & \\
\hline Sixtdik Mresu 4 & $120,93 \div 7,28$ & $141,53 * 23,34$ & \\
\hline Destolik Mingeu 1 & $90,47 \pm 6,66$ & $B 8,07 \pm 14,54$ & \\
\hline Pastedik Minues 2 & $84,53 \times 6,35$ & $9993+14,4$ & 0,037 \\
\hline Dlastolik Minery 3 & $82,60-5,53$ & $91,60+12,44$ & \\
\hline Diantelik Minpau 4 & $81,07 \pm 4,16$ & $92,07+11,51$ & \\
\hline
\end{tabular}

Anova Repeated Measure

Gambar 2 menunjukkan hasil analisis uji statistik menggunakan uji Anova Repeated Measure, tekanan darah sistolik kelompok perlakuan yang diberikan smoothies kombinasi aneka buah dan sayur mengalami penurunan drastis pada minggu ke- 2 dan menurun secara bertahap pada minggu ke-3 dan minggu ke 4 . Tekanan darah sistolik pada kelompok kontrol mengalami kenaikan pada pengukuran ke-2 dan mengalami penurunan secara bertahap pada minggu ke-3 dan minggu ke-4. Menurut hasil analisis terdapat hubungan / pengaruh antara pemberian smoothies kombinasi aneka buah dan sayur terhadap tekanan darah sistolik $(p=0,025)$.

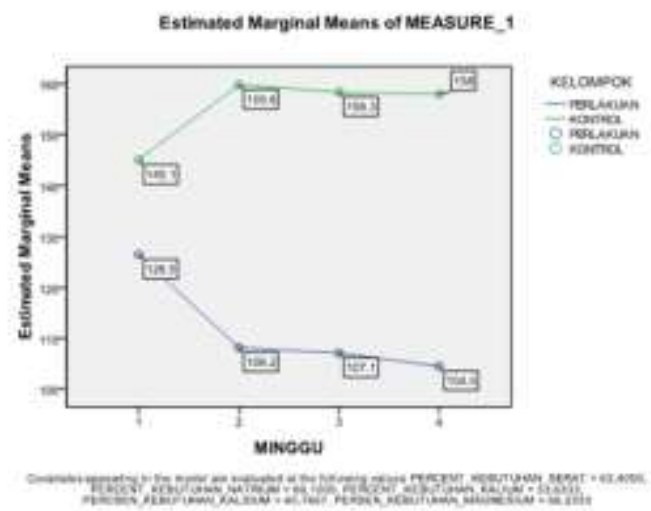

Gambar 2.Grafik Tekanan darah sistolik antara kelompok kontrol dan kelompok perlakuan setiap pengukuran selama penelitian dengan variabel yang dikontrol asupan serat, natrium, kalium, kalsium dan magnesium.

Gambar 3 menunjukkan hasil analisis menggunakan uji Anova Repeated Measure, tekanan darah diastolik kelompok perlakuan yang diberikan smoothies kombinasi aneka buah dan sayur mengalami penurunan secara drastik pada minggu ke-2 dan mengalami penurunan sedikit dan cenderung stabil pada minggu ke-3 dan ke-4. Tekanan darah diastolik pada kelompok kontrol mengalami kenaikan pada pengukuran ke-2 dan mengalami penurunan pada minggu ke-3 dan ke-4. Namun secara uji staistik multivariat dengan variabel konfonding serat, natrium, kalium, kalsium dan magnesium terdapat hubungan / pengaruh antara pemberian smoothies kombinasi aneka buah dan sayur terhadap tekanan darah sistolik $(p=0,037)$.

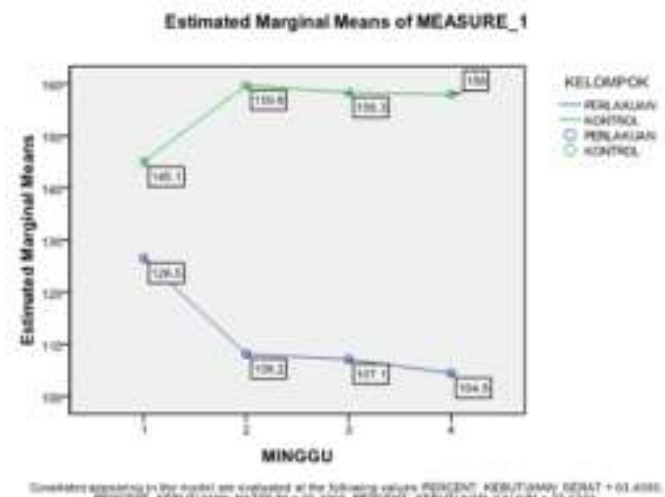

Gambar 3. Grafik Tekanan darah diastolik antara kelompok kontrol dan kelompok perlakuan setiap pengukuran selama penelitian dengan variabel yang dikontrol asupan serat, natrium, kalium, kalsium dan magnesium

\section{PEMBAHASAN}

\section{Krakteristik Subjek Penelitian}

Berdasarkan analisis karakteristik sampel penelitian pada tabel 1 dikatahui bahwa umur sampel penelitian sebagian besar termasuk dalam kategori dewasa (30-49 Tahun) dengan status gizi obesitas tipe I (25,0 -29,9 $\mathrm{kg} / \mathrm{m}^{2}$ ). Menurut Institut Kesehatan Nasional Amerika (NIH), resiko hipertensi menjadi dua sampai enam kali lipat pada seseorang dengan status gizi berlebih. Obesitas dapat meningkatkan volume plasma dan curah jantung yang akhirnya mengakibatkan terjadinya peningkatan tekanan darah. ${ }^{2}$ Diketahui sebagian besar (63,3 \%) sampel penelitian adalah pekerja. Pekerjaan dapat menimbulkan strees pada sesorang akibat bertambahnya beban fikiran sesorang. Stress yang berlebihan dapat menimbulkan peningkatan tekanan darah. 
Tekanan darah merupakan daya dorong yang diberikan jantung kepada darah untuk melawan dinding darah (arteri) saat memompa darah keluar dari jantung menuju seluruh tubuh. ${ }^{10}$ Tekanan darah terdiri dari tekanan darah sistolik dan tekanan darah diastolik. Tekanan darah sistol merupakan tekanan darah yang terukur akibat proses mengalirnya darah ke pembuluh darah sehingga pembuluh darah meregang maksimal akibat ventrikel kiri jantung berkontaksi (sistole). ${ }^{11}$ Sedangkan tekanan darah diastol adalah tekanan darah pada saat jantung berelaksasi (distole). ${ }^{11}$ Menurut Kemenkes (2013) tekanan darah normal berkisar antara $\leq 120 / 80 \mathrm{mmHg}$.

Berdasarkan tabel 2 rerata tekanan darah sistolik dan diastolik sampel penelitian sebelum perlakuan sebesar $137 / 90 \mathrm{mmHg}$ pada kelompok perlakuan dan 133/80 $\mathrm{mmHg}$ pada kelompok kontrol. Klasifikasi hipertensi menurut Kemenkes RI tahun 2013 rerata tekanan darah kelompok perlakuan dan kelompok kontrol termasuk dalam kategori pre hipertensi. Kondisi ini jika tidak mendapatkan penangan yang tepat dapat berkembang menjadi masalah hipertensi di kemudian hari. ${ }^{12}$

Tekanan darah yang tinggi terutama pada usia dewasa disebabkan struktur pembuluh darah yang mengalami perubahan seperti penurunan elastisitas pembuluh darah yang menyebabkan tekanan darah semakin meningkat. ${ }^{13,20}$ Semakin bertambahnya usia wanita (memasuki menopause) akan mengakibatkan produksi hormon esterogen menurun yang mengakibatkan penurunan $\mathrm{HDL}$ (High Density Lipoprotein) dan kenaikan LDL (Low Density Lipoprotein). Tingginya kadar kolesterol LDL mengakibatkan penyempitan dinding pembuluh darah sehingga terjadi aterosklerosis yang meingkatkan tekanan darah. ${ }^{14,15}$

Pada penelitian ini banyak dijumpai orang yang berusia 30-49 tahun memiliki tekanan darah sistolik dan diastolik yang tergolong dalam kategori prehipertensi sebanyak $73,3 \%$. Tingginya tekanan darah pada orang dewasa juga disebabkan karena asupan makan yang tidak sesuai dengan kebutuhan. Asupan buah dan sayur pada sampel penelitian berkisar 1-2 kali sehari menyebabkan asupan serat dan kalium hanya mencukupi kebutuhan sebanyak $63,4 \%$ serat dan $33,6 \%$ kalium.

\section{Asupan Smoothies Selama Penelitian}

Kepatuhan konsumsi smoothies kombinasi aneka buah dan sayur pada minggu pertama sampai minggu ke tiga termasuk dalam kategori baik yaitu diatas $95 \%$ dengan cut of point $80 \%$. Pemberian smoothies buah dan sayur yang memiliki konsentrasi kental sebanyak $350 \mathrm{ml}$ menyebabkan kelompok perlakuan menjadi mudah kenyang sehingga tidak bisa menghabiskan semua smoothies yang diberikan.

Smoothies Kombinasi wortel, alpukat dan jambu biji merupakan kombinasi yang paling disukai oleh sampel penelitian dengan tingkat kepatuhan sebanyak $99 \%$. Kombinasi ini menyumbang asupan serat dan kalium paling banyak dibandingkan dengan kombinasi lainnya yaitu sebanyak $14,9 \mathrm{gr}$ atau $59,6 \%$ dari total kebutuhan serat sehari dan asupan kalium sebanyak $1.222 \mathrm{mg}$ atau $26 \%$ dari total kebutuhan kalium setiap harinya. Asupan serat sebanyak 69,6 \% membuat sampel merasa kenyang lebih lama sehingga menggeser pola makan utama pada kelompok perlakuan menjadi 2 kali makan utama. ${ }^{16,17}$

3. Hasil Analisis Asupan Sampel Sebelum dan Sesudah Penelitian

Berdasarkan tabel 4 diperoleh kategori asupan serat, natrium, kalium, kalsium dan magnesium pada sampel penelitian sebelum perlakuan antara kelompok perlakuan dan kelompok kontrol yang di analisis menggunakan uji Independent Sampel-Test menunjukkan tidak ada perbedaan yang signifikan $(p>0,005)$. Hal ini menunjukan data asupan sebelum penelitian antara kelompok perlakuan dan kelompok kontrol tidak berbeda pada kehidupan seharihari.

Hasil analisis menggunakan uji Independent Sampel-Test menunjukkan ada perbedaan yang signifikan asupan serat dan kalium pada sampel penelitian selama perlakuan $(p<0,005)$. Perbedaan asupan serat dan kalium antara kelompok kontrol dan kelompok perlakuan terjadi karena adanya pemberian smoothies kombinasi aneka buah dan sayur kepada kelompok perlakuan selama 21 hari. Smoothies kombinasi aneka buah dan sayur diberikan sebanyak $350 \mathrm{ml}$ setiap hari dengan siklus 4 hari untuk 4 variasi yang berbeda.

4. Pengaruh Pemberian Smoothies Kombinasi Aneka Buah dan Sayur Terhadap Perubahan Tekanan Darah 
Tabel 5 menunjukkan hasil analisis statistik menggunakan uji Mann Whitney bahwa tidak ada perbedaan yang signifikan terhadap tekanan darah sistolik dan diastolik antara kelompok perlakuan dan kelompok kontrol $(p=0,191$ dan $p=0,104)$. Namun ada perbedaan yang signifikan terhadap tekanan darah sistolik dan diastolik antara kelompok perlakuan dan kelompok kontrol setelah perlakuan $(p=0,000$ dan $p=0,001)$. Hal ini membuktikan bahwa smoothies kombinasi aneka buah dan sayur yang diberikan selama 21 hari dapat menurunkan tekanan darah sistolik dan diastolik pada kelompok perlakuan sebanyak $16,8 \mathrm{mmHg}$ dan $9,4 \mathrm{mmHg}$.

\section{Perubahan Tekanan Darah Sebelum dan Sesudah Penelitian}

Berdasarkan gambar 2 yang dianalisis menggunakan uji Anova Repeated Measure menunjukkan bahwa tekanan darah sistolik kelompok perlakuan yang diberikan smoothies kombinasi aneka buah dan sayur mengalami penurunan drastis pada minggu ke-2, menurun secara stabil pada pengukuran ke-3 dan ke 4 . Sedangkan tekanan darah sistolik pada kelompok kontrol mengalami kenaikan pada pengukuran ke-2 dan mengalami penurunan secara bertahap pada minggu ke-3 dan ke-4. Secara uji staistik multivariat dengan variabel yang dikontrol yaitu asupan serat, natrium, kalium, kalsium dan magnesium terdapat hubungan / pengaruh antara pemberian smoothies kombinasi aneka buah dan sayur terhadap tekanan darah sistolik $(p=0,025)$.

Berdasarkan gambar 3 yang dianalisis menggunakan uji Anova Repeated Measure menunjukkan bahwa tekanan darah diatolik kelompok perlakuan yang diberikan smoothies kombinasi aneka buah dan sayur mengalami penurunan drastis pada pengukuran ke-2 dan ke-4 dan mengalami kenaikan sedikit pada pengukuran ke 3. Tekanan darah sistolik pada kelompok kontrol mengalami kenaikan pada pengukuran ke-2 dan mengalami penurunan sedikit pada pengukuran ke-3 dan ke-4. Namun secara uji staistik multivariat dengan variabel dikontrol yaitu asupan serat, natrium, kalium, kalsium dan magnesium terdapat hubungan / pengaruh antara pemberian smoothies kombinasi aneka buah dan sayur terhadap tekanan darah sistolik ( $p=0,037)$.

Pada gambar 2 dan 3 menunjukkan adanya penurunan tekanan darah sistolik dan diastolik pada kelompok kontrol maupun kelompok perlakuan. Pada pengukuran tekanan darah sistolik dan diastolik pada minggu ke-2 terjadi penurunan tekanan darah secara drastis pada kelompok perlakuan. Hal ini mungkin dikarenakan tubuh mencoba beradaptasi dengan pemberian perlakuan berupa smoothies kombinasi aneka buah dan sayur.

Penurunan tekanan darah sistolik dan diastolik selama penelitian sesuai dengan penelitian yang dilakukan Inggita, et al (2016) yang mengatakan bahwa ada korelasi antara asupan kalium dengan tekanan darah sislokik dan diastolik pasien hipertensi $(p=0,000) .{ }^{18}$ Kontribusi smoothies kombinasi aneka buah dan sayur dari pemberian sehari yaitu 59,6\% serat dan $26 \%$ kalium. Serat dapat menurunkan tekanan darah dengan cara mengurangi kadar kolesterol dalam sirkulasi darah sebanyak $5 \%$ atau lebih. Serat pangan dapat mengikat garam empedu, meningkatkan ekskresi asam empedu dan mencegah absorbsi kolesterol dalam usus. ${ }^{19,20,21}$ Teori ini didukung oleh penelitian yang dilakukan Galisteo, et. al. (2008) menyatakan bahwa asupan serat yang tinggi selama 6 minggu menurunkan kadar trigliserida sebanyak 10,2 \%. ${ }^{22}$ Penelitian lain yang dilakukan di Brazil tahun 2012 mengungkapkan bahwa pemberian serat larut air selama 3 hari kepada subjek obesitas berdampak terhadap penurunan tekanan darah. ${ }^{23}$

Menurut Pusporini (2009) kalium dapat berfungsi sebagai pengatur cairan intrasel sehingga mencegah penumpukan cairan dan natrium yang dapat menigkatkan tekanan darah. ${ }^{24}$ Kalium juga berfungsi sebagai vasodilator dengan dengan menurunkan tahanan perifer dan meningkatkan curah jantung sehingga menurunka tekanan darah. Selain itu kalium juga berfungsi mengubah aktifitas renin angiotensin dengan menghambat renin angiotensin $1{ }^{25}$ Hasil penelitian ini juga sesuai dengan penelitian yang dilakukan oleh Sagiman (2015) yang menunjukkan bahwa penambahan asupan kalium dari jus jambu biji dapat menurunakan tekanan darah sistolik dan diastolik dengan $\mathrm{p}$ value masing-masing $\mathrm{p}=0,005$ dan $\mathrm{p}=0,004 .^{26}$

Smoothies kombinasi aneka buah dan sayur yang diberikan selama penelitian mengandung zat gizi mikronutrien serta mengandung flavonoid dan lycopene. Flavonoid dapat menurunkan penyerapan kolesterol penyebab arterosklerosis dan mengabsorbsi cairan ion-ion elektrolit seperti natrium yang ada di intraseluler untuk menuju ekstraseluler memasuki tubulus ginjal. ${ }^{6}$ Flavonoid juga dapat menghambat enzim pengubah angiotensin, antagonis kalium dan dapat mencegah otot 
dinding pembuluh darah berkontraksi (fungsi vasodilator). ${ }^{27}$

Zat lycopene berfungsi sebagai kardioprotektif dengan menghambat agregasi platelet atau aktifitas antiplatelet dan memperlambat arterosklerosis dengan peningkatan degradasi LDL sehingga mencegah tersedianya oksidasi LDL serta berfungsi sebagai antiarterosklerosis. ${ }^{20}$ Studi yang dilakukan di Australia dengan memberikan ekstrak likopen sebanyak $\geq 25 \mathrm{mg} /$ hari efektif untuk menurunkan serum kolesterol total dan LDL serta menurunkan tekanan darah sistolik sebesar 5,26 mmHg. ${ }^{28}$

Penambahan jeruk nipis selama pembuatan smoothies menyumbang asupan vitamin C yang membantu menurunkan tekanan darah. Vitamin C dapat meningkatkan ketersediaan hayati nitric oxide yang memiliki efek antihipertensi. ${ }^{29}$ Vitamin $\mathrm{C}$ juga diduga dapat memodulasi pengeluaran nitric oxid (NO). ${ }^{30}$ Menurut Taddei, et al Nitric oxide merupakan Endotel Derived Releasting Factor (EDRF) yang dapat berfungsi sebagai vasodilator da pelicin bagi pelekatan LDL dan sel-sel darah sehingga tidak terjadi pelekatan pada dinding pembuluh darah. ${ }^{6}$

\section{KESIMPULAN DAN SARAN}

\section{KESIMPULAN}

Rata-rata tekanan darah sistolik dan diastolik pada kelompok perlakuan menuruun $16,80 \mathrm{mmHg}$ dan $9,40 \mathrm{mmHg}$ setelah diberikan smoothies kombinasi aneka buah dan sayur, sedangkan kelompok kontrol cenderung meningkat karena tidak diberi smoothies.

\section{SARAN}

Smoothies kombinasi aneka buah dan sayur dapat digunakan sebagai alternatif untuk menurunkan tekanan darahs sistolik dan diastolik menggunakan kombinasi buah dan sayur seperti alpukat, buah naga, jambu biji, tomat, wortel, pisang, bengkuang, dan mentimun.

\section{DAFTAR PUSTAKA}

1. Badan Penelitian Dan Pengembangan Kesehatan Kementerian Kesehatan Ri. Riset Kesehatan Dasar. Jakarta; 2013.

2. Lestari AP. Pengaruh Pemberian Jus Tomat ( Lycopersicum Commune ) Terhadap Tekanan Darah Pada Wanita Postmenopause Hipertensi. J Gizi Indones. 2012;

3. Prasetyo SD, Chrisandyani D. Gambaran Efek
Samping Obat Antihipertensi Pada Pasien Hipertensi Di Instalasi Rawat Inap RS PKU Muhammadiyah Yogyakarta Periode OktoberNovember 2009. J Pharm. 2010;6(1410590X):22-4.

4. Muchid A, Umar F, Chusun, Masrul, Wurjati R, Purnama NR, Et Al. Pharmaceutical Care Untuk Penyakit Hipertensi. Jakarta: Direktorat Bina Kefarmasian Dan Alat Kesehatan Departemen Kesehatan; 2006.

5. Ilma AD. Pengaruh Pemberian Jus Mentimun Dan Tomat Terhadap Tekanan Darah Perempuan Overweight Dan Obesitas. J Gizi Indones. 2015;1-17.

6. Nisa FK. Pengaruh Pemberian Jus Buah Naga Merah (Hylocereus Polyrhizus) Terhadap Penurunan Tekanan Darah (Studi Di Wilayah Kerja Puskesmas Kaliwates Kabupaten Jember). J Kesehat Masy. 2017;

7. Franco, Belen M, Montserrat LL, Eva MAE. Soluble And Insoluble Dietary Fiber Intake And Risk Factors For Metabolic Syndrome And Cardiovascular Disiese In Middle-Aged Adult : The AWHS Cohort. J Nutr Hosp. 2014;6(30):1279-88.

8. Joint G, Committee N. ANALISIS JNC 8: Evidence-Based Guideline Penanganan Pasien Hipertensi Dewasa. 2016;43(1):54-9.

9. Setyorini T. Ini Perbedaan Jus Dan Smoothies, Sudah Tahu? Merdeka.Com. 2015.

10. Ronny, Setiawan, Fatimah S. Fisiologi Kardiovaskular Berbasis Masalah Keperawatan. 2nd Ed. Wahyuningsih E, Editor. Jakarta: EGC; 2010. 26-34 P.

11. Pusat Data Dan Informasi Kementerian Kesehatan RI. Infodatin Hipertensi. Jakarta Selatan; 2014.

12. Kemenkes RI. Pedoman Teknis Penemuan Dan Tatalaksana Hipertensi. Revisi 201. Jakarta; 2013.

13. Lenny, Danang. Hipertensi. Jakarta: PT. Grasindo; 2008.

14. Murai RK, Daryl KG, Etal. Biokimia Harper. 27th Ed. Jakarta: EGC; 2008.

15. Couch SC. Medical Nutrition Therapy For Hypertension, In: Mahan LK, Escott-Stump. Saunders, Editor. USA; 2008.

16. Ventura E, Davis J, Alexander K, Shaibi G, Lee W, Byrd-Williams C. Dietary Intake And The Metabolic Syndrome In Overweight Latino Children. J Am Diet Assoc. 2008;108 (8)(1355):9.

17. Carlos J, Joey CE, Gregory JN, Karen AO, Paul CY. Dietary Fiber And Nutrient Density Are Inversely Associted Whit The Metabolic Syndrom In US Adolenscents. J Am Diet Assoc. 2011;111:1688-95. 
18. Kusumastuty I, Widyani D, Wahyuni E Sri. Asupan Protein Dan Kalium Berhubungan Dengan Penurunan Tekanan Darah Pasien Hipertensi Rawat Jalan. Indones J Hum Nutr. 2016;3(1):19-28.

19. Muchtadi D. Sayuran Sebagai Sumber Serat Pangan Untuk Mencegah Timbulnya Penyakit Degeneratif. J Tekno Dan Pangan. 2001;62-71.

20. Peter M, Rolfes S, Pinna K, Whitney E. Understanding Normal And Clinical Nutrition. In: 7th Ed. USA; 2002.

21. Dauchet L. Dietary Pattern And Blood Pressure Change Over 5-Y Follow-Upin The SU. J Clin Nytrition. 2009;85(1650):6.

22. Galisteo M, Duarte J, Zarzuelo A. Effect Of Dietary Fibers On Disturbances Clustered In The Metabolic Syndrome. J Nutr Biochem. 2008;19(2):71-84.

23. EP De O, KC ML, Vas De ASL, Burini L. Dietary Factors Associated Ehit Metabolic Syndrome InBrazilia Adults. Nutr J. 2012;(11):13.

24. Pusporini M. Cara Mudah Mengatasi Hipertensi. Yogyakarta: Image Press; 2009.

25. Banner, Suddarti. Keperawatan Medical Bedah. In: 3rd Ed. Jakarta: EGC; 2002.

26. Sagiman. PENGARUH PEMBERIAN JUS JAMB BIJI TERHADAP. J Keperawatan. 2015;

27. Handayani TRIW. Studi Komparasi Pemberian Jus Semangka Dan Jus Belimbing Terhadap Tekanna Darah Pada Penderita Hipertensi Di Dusun Gamping Kidul Sleman Yogyakarta. J Unisa. 2017;

28. Ried K, Fakler P. Protective Effect Of Lycopene On Serum Cholesterol And Blood Praesure: Meta-Analysis Of Intervention Trial. Maturitas [Internet]. 2011;68(299). Available From: Www.Elsevier.Com/Locate/Maturitas

29. Grober U. Mikronutrien: Penyelarasan Metabolik, Pencegahan Dan Terapi. H A, Aini N, Editors. Jakarta: EGC; 2012.

30. Higdon J. Vitamin C [Internet]. Micronutrient Information Center Espanol :Linux Institute,

31. Oregon State University. 2013 [Cited 2018 May 3]. Available From: Http://Www.Lpi.Oregonstate.Edu/Mic/Vitami ns/Vitamin-C 